\title{
Utilization of Spent Millet from Locally Fermented Drink (Burukutu) As Experimental Diets for Clarias gariepinus
}

\author{
${ }^{* 1}$ OGBE, KU; ${ }^{2}$ ADIKWU, IA; ${ }^{2}$ AKOMBO, PM; ${ }^{1}$ DASUMA, E \\ *IDepartment of Animal and environmental Biology, Kogi State University Anyigba, Nigeria \\ ${ }^{2}$ Department of Biological sciences, Benue State University Makurdi, Nigeria \\ *Corresponding Author Email: ogbekingsley90@gmail.com
}

\begin{abstract}
ABTRACT: Brewer's waste is one of the promising carbohydrate and protein source by-products for fish diets. A 10-wk feeding trial experiment involving 10 different diets (10 diets for Spent millet, from locally fermented drink (Burukutu) with increasing levels of brewer's waste $(40 \%$ crude protein) was carried out to evaluate the use of spent millet, from Burukutu production in Clarias gariepinus diets in place of normal Corn. Growth performance was compared against a control diet formulated to have similar composition to a typical commercial diet. 10 experimental diets replaced successively $0 \%, 10 \%, 20 \%, 30 \%, 40 \%, 50 \%, 70 \%, 80 \%, 90 \%$, and $100 \%$ of the Corn carbohydrate with Spent millet from locally fermented drink, Burukutu.. The diets were isonitrogenous and isocaloric. A relatively good growth performance and nutrient utilization by Clarias gariepinus fed the test diets were observed. However, the results showed significant difference $(\mathrm{p}<0.05)$ in weight gain, SGR, FCR and RGR between treatments, with the control performing best. The result also showed that survival rate was high in all the treatment which indicate that, spent millet from burukutu production has no adverse effect on the experimented fish. Based on this research, it wasconcluded that $50 \%$ of the corn carbohydrate in a typicalcommercial diet could be replaced with spent grain (millet) from locally fermented drink (BKT) withno adverse effect on growth and feed utilization for Clarias gariepinus.
\end{abstract}

\section{DOI:https://dx.doi.org/10.4314/jasem.v25i9.23}

Copyright: Copyright $\left({ }_{0} 2021\right.$ Ogbe et al. This is an open access article distributed under the Creative Commons Attribution License (CCL), which permits unrestricted use, distribution, and reproduction in any medium, provided the original work is properly cited.

Dates: Received: 09 May 2021; Revised: 12 August 2021; Accepted: 12 September 2021

Keywords: spent millet, Burukutu, Growth response, Nutrient utilization and C. gariepinus.

The current trend of inflation worldwide has become a basic concern for livestock owners, inflation often imposes adverse effects on livestock feeds and hence, on costs of producing livestock and livestock products (Nyannor et al., 2007). It has been estimated that, 60 percent of world fish meal production and 88 percent of world fish oil production will be utilized by Aquaculture. (Huntingon and Hasan, 2009). Consequently, one of the greatest challenges facing the African continent is the provision of sufficient food to the ever increasing population which is not matched with similar increase in food production (Fasuyi, 2005). The increasing demand for animal protein has aroused great interest in the production of fast growing animals with short generation intervals (Apantaku et al., 1998). In 2009, fish accounted for $17 \%$ of the world population animal protein intake and $6.5 \%$ of all protein consumed (FAO, 2012). Global population has grown substantially in the past decade, reaching 7 billion in 2012, compared with 6 billion in 2000. This increasing world population indirectly rising the demand of protein for human consumption and animal production. Moreover, it is predicted that for the coming 20 years, there will be more than 8 billion people standing on the earth (Heyden,
2010).Therefore, there is the need to seek new food source with promising high protein and nutrient to meet food demand problem. Aquaculture has been suggested to have the greatest possibility in meeting the protein demand supply gap. Though, the growth of aquaculture is restrained by the low availability and higher price of all quality aqua feed ingredients. In other word, the financial viability of aquaculture investments is highly dependent on the cost paid for aqua feeds, which generally account for $50-70 \%$ of production cost (FAO Fisheries and Aquaculture Department, 2011). It has been estimated that, by 2012, 60 percent of world fishmeal production and 88 percent of world fish oil production will be used by aquaculture Conversely, the increased competition between the expanding aquaculture and livestock sectors for a limited supply of fishmeal and fish oil continues to drive the price upwards and that the price could reach a level where the use of fishmeal and fish oil may no longer be financially viable (FAO of the United Nations, 2006). Hence, due to the limited availability and the rising price of fish meal, an impressive amount of studies have been carried out in recent decades to reduce dependency of fish meal. Several attempts have been made by researchers to 
increase the utilization of nonconventional plant and animal materials to replace conventional feed ingredients like corn and fish meal in fish feed ration (Baruah et al., 2003; Eyo, 2004; Eyo and Ezechie, 2004; Abu et al., 2010; Jimoh et al., 2014). Olurin et al. 2006) reported that the digestibility of corn has made it the major source of metabolizable energy in most compounded diets for catfish species. Corn, although widely cultivated has been extensively utilized as human food, feed for livestock and raw materials for industries (Eyo and Ezechie, 2004). In Nigeria, the demand for corn is in excess of production, and the utilization of corn as major basal ingredients in the aquaculture industries will place more constraint on an already over exploited resource. There is therefore, the need to exploit cheaper energy sources to replace expensive corn in fish feed formulation.

\section{METERIALS AND METHOD}

Study Area: The experiment was conducted in Anyigba, Kogi State. Anyigba is a town in Dekina local government area of Kogi State with headquarter in Dekina town. The study area is on the A233 highway in the north of the area at $7041^{\prime} 4^{\prime \prime} \mathrm{N}$ and 70 $01^{\prime} 20^{\prime \prime} \mathrm{E}$.The north easterly line of equal latitude and longitude passes through the south east of the local government area. It has an area of $2.461 \mathrm{~km} 2$ and a population of 260,312 at the 2006 census.

Source and processing of brewer's waste: Spent millet was sourced from a local gin producer at Agume in dekinal local government and Ejegbo in Ankpa local government. Brewery waste in fresh form contains about 80-85\% moisture, in order to utilize it in feed, the waste was sundried for 7 days., continues sundering of wastes for 7 days rendered it moisture free, with regular turning to prevent moldiness. Thereafter samples was milled and taken for proximate analysis. The completely dried brewery waste was ground thoroughly and following mixing with other feed ingredients (fish meal soybean meal, corn, vitamin/mineral premix), the mixture was again ground. Ingredients used in the feeding trial: fishmeal, soybean meal, corn, vitamin/mineral premix, were bought from Ilorin market,Kwara State, Nigeria. These ingredients were separately milled, screened with fine mesh net to fine particle size $(<250 \mu \mathrm{m})$.

Experimental diets: (Ten (10) isonitrogenous experimental diets were formulated. 10 diets containing progressively increasing levels of Spent Millet (SML) from BKT production were formulated for the feeding trial experiment. The experimental diets were formulated to produce diets in which $0 \%$ (SML0), $10 \%$ (SML10), 20\% (SML20), 30\% (SML30), $40 \% \quad$ (SML40), $50 \% \quad$ (SML50) $70 \%$ (SML70) 80\% (SML80) 90\% (SML90) and100\% (SML100) of carbohydrate from corn were replaced with that from Spent Sorghum (SML) (Table 1). The feedstuffs were finely grounded and mixed in plastic bowl. With the addition of boiling water, they formed dough. The mixture was then pelleted by passing it through a mincer of $2 \mathrm{~mm}$ die to produce $2 \mathrm{~mm}$ diameter size of pellets. The feed was sundried to about $10 \%$ moisture content, packed in polythene bags and kept safe in a dry place until used.

Table 1: Percentage composition of experimental diet fed to Clarias gariepinus (spent millet)

\begin{tabular}{lllllllllll}
\hline & \multicolumn{10}{c}{ DIETS } \\
\cline { 2 - 11 } & $0 \%$ & $10 \%$ & $20 \%$ & $30 \%$ & $40 \%$ & $50 \%$ & $70 \%$ & $80 \%$ & $90 \%$ & $100 \%$ \\
\hline Ingredients (\%) & & & & & & & & \\
\hline Fish meal & 36.70 & 36.50 & 36.33 & 36.13 & 35.94 & 36.51 & 35.32 & 35.10 & 34.90 & 34.67 \\
Soya beans & 24.47 & 24.35 & 24.21 & 24.09 & 23.95 & 23.82 & 23.54 & 23.41 & 23.25 & 23.11 \\
Maize & 34.83 & 31.63 & 28.37 & 25.05 & 21.67 & 18.22 & 11.14 & 7.50 & 3.79 & 0.00 \\
Spent millet & 0 & 3.51 & 7.09 & 10.74 & 14.45 & 18.22 & 25.99 & 29.99 & 34.07 & 37.68 \\
Vit/min. & 2 & 2 & 2 & 2 & 2 & 2 & 2 & 2 & 2 & 2 \\
Starch & 2 & 2 & 2 & 2 & 2 & 2 & 2 & 2 & 2 & 2 \\
\hline
\end{tabular}

Culture condition: A total number of 1,200 Fingerlings of $C$. gariepinus, was purchased and transported to Anyigba, Kogi state using an oxygen air bag. They were acclimatized for one week in concrete holding tanks of $7.0 \mathrm{~m} \times 4.0 \mathrm{~m} \times 2.0 \mathrm{~m}$, and with a feed of $40 \%$ crude protein. Fishes were sorted, weighed (using a sensitive weighing balance) and randomly stocked into the experimental bowls at the rate of 12 fish per tank. They were starved overnight before the commencement of the feeding trials (Ayinla, 2007). At the end of acclimation, fish in each tank were weighed to determine their initial mean weight. Fish were offered $5 \%$ of their body weight. Feeding was done $8.00 \mathrm{am}-9 \mathrm{am}$ and $5.00 \mathrm{pm}-6 \mathrm{pm}$ (i.e., twice daily) at a rate equivalent to about $5 \%$ of the total body weight of the fish in each pond .Fish in each pond was weighed weekly and the readings obtained was used to compute parameters like mean weight gain (MWG), Specific Growth Rate (SGR), Protein Efficiency Ratio (PER) and other growth and nutrient utilization parameters. They was a daily monitored for mortality. Dead fish was removed, counted and recorded. Growth response and feed utilization indices were estimated according to Jimoh and Aroyehun (2011). 
Experimental set up: there were 10 different treatments. Each of the treatment have three replicates. Making it a total of 30 bowls containing 12 fishes for each bowl, making a total of 360 fingerlings for the first experiment. For experiment two, they were 10 different treatments. Each of the treatment have three replicates. Making it a total of 30 bowls containing 12 fishes for each bowl, making a total of 360 fingerlings for the first experiment. For experiment three, they were 10 different treatments. Each of the treatment have three replicates. Making it a total of 30 bowls containing 12 fishes for each bowl, making a total of 360 fingerlings for the first experiment. In total for the three experimental set up, they were 90 bowls, which contain 12 fishes, making a total of 1080 fingerlings of Clarias gariepinus for the feeding trials.

Data collection: During data collection, the sample catfish were removed from the Bowls. Each of the 12 catfish from each Bowl as per the treatment diet were weighed. All measurements on body weight, feed intake, were carried using a weighing balance.

Water quality management: Water level: The water sources for the experiment was from bore hole. Each basin was filled about 40 litters of water and the water is being changed every three days. The following physiochemical parameters of the water was monitored during the period of the experiment.

$p H$ :(Hydrogen ion concentration): The $\mathrm{pH}$ of the water was determined using a $\mathrm{pH}$ meter.

Temperature: The common glass thermometer dry bulb) was used to determine water temperature weekly. The bottom of the thermometer was dipped into the water, while the mercury inside was thoroughly observed. The points at which it stopped rising was taken as the temperature reading of the water.

Dissolved oxygen, $\mathrm{HN}_{3}, \mathrm{NO}_{3}$ and $\mathrm{NO}_{2}$ was also determined in Biochemistry lab, Kogi state university anyigba

Proximate Analysis: The nutritional composition of SBG sample were analyzed in triplicate according to Weende proximate analyses (Fisheries and Aquaculture Department, 1994).

Feed evaluation parameters: The following growth and nutrient utilization parameters will be calculated as measures of the effectiveness of utilization of SBW meal as a replacement in the diet of Clarias gariepinus. This will be done in accordance with the method of Brown (1975).

Weight gain: This is calculated mathematically as the difference between the final mean weight and initial mean weight of all fish in a bowl. This was calculated as follows:

$$
\text { weigh gain }=\frac{\operatorname{loge} w t-\log w o}{\text { numbers of days }} \times 100
$$

Were wo $=$ initial weight of the fish at the start of the experiment (in gram); Wt. =final weight of fish at the end of the experiment; e =base of natural logarithm

Food conversion ratio: Is calculated thus as

$$
\frac{\text { average food taken (in gram) }}{\text { body weight gain }(\text { gram) }}
$$

Relative growth rate: This is express as

$$
\text { food converion raio }=\frac{w t-w o}{w o} \times 100
$$

Where $\mathrm{w}_{\mathrm{t}}$. is the final weight of the fish at the experiment (in gram); $\mathrm{W}_{\mathrm{o}}$ is the initial weight of the start of the experiment.

Protein Efficiency Ratio (PER): This is calculated from the relationship between the increment in the body weight of fish (i.e. the weight gain of fish) and protein consumed according to the methods described by Booth and Allan (2003)

$$
\text { proein Efficiency Ratio }=\frac{\text { mean weight gain }}{\text { proein inake }}
$$

Weekly growth rate: (Oyedele, 2007)

$$
=\frac{\text { means increase in weight per week }}{\text { initial body weight of fish }}
$$

Cross efficiency of food conversion: (Tsicknay, 1969)

$$
=\frac{\text { Weekly rare of growh }}{\text { weekl rate of feeding }}
$$

Means weight of fish: (Lovell, 1972)

$$
=\frac{\text { Total weight of fish }}{\text { numbers of } \text { fish }}
$$

Mean weight gain per week: Final mean weight gain per week - initial means weight gain per day

Percentage weight gain per week (Halver, 1976)

$$
=\frac{\text { Mean weight gain per week }}{\text { mean weight }} \times 100
$$

Cross food conversion efficiency in, \%: This will be calculated as the reciprocal of the food conversion ratio expressed as percentage (stickey, 1980)

(1/FCR X 100/1) 
Protein intake: $=\frac{\text { Total feed consumed } \times \% \text { proein intake }}{100}$

Specific growth rate:

$$
=\frac{\log e w 2-\log w 1 \times 100 \times 100}{T 2-T 1 \times W 1}
$$

Where $\mathrm{W} 2$ =weight at time $\mathrm{t} 2$ day; $\mathrm{W} 1=$ weight at time T1 (days)

Statistical analysis: Collected weights were recorded in workbooks and the raw data was transferred into excel spreadsheets for organization and cleaning. All determinations were conducted in triplicates and the means were subjected to Analysis of Variance, where, the ANOVA revealed a significant difference, and significantly different means were separated by using Duncan at $\mathrm{P}<0$ 0.05.SPSS version 20.0

\section{RESULTS AND DISCUSION}

Growth parameters of the experimented fish: Result of the growth response and feed utilization data for $C$. gariepinus fed the 10 diet of Spent Millet (SML) meal are presented in Table 2. The highest mean weigh gram (MWG) was observed in fishes fed with control diet at $68.52 \mathrm{~g}$, followed by $10 \%$ as $66.6 \mathrm{~g}$. The lowest MWG was observed in $100 \%$ and $90 \%$ at $29.1 \mathrm{~g}$ and
$31.00 \mathrm{~g}$ respectively. There is a significant differences between MWG of fishes fed control diet and 10\% BSG meal. While significant difference exist between the control diet and the rest except 10\% SML meal. The average daily weight (ADW) was highest in fishes fed control diet at 0.86 and lowest in fishes feed $100 \%$ at BSG at 0.42. There was no significance difference In ADW between the fish feed with control diet and fishes fed $20 \%$ and 30\% SML meal. The result for the specific growth rate (SGR) showed that fishes fed control diet had the highest value of $85.98 \%$. There was no significance difference between the SGR of fishes fed with control diet and 10\% SM meal. Significance difference exist between the control and the rest of the diet except 10\% SML meal. The result of the relative growth rate (RGP) signified that fishes fed control diet has the highest value on $722.80 \%$ followed by $10 \%$ at $700.27 \%$. There is significance difference between the control diet and the rest of the diet except for $10 \%$ SM diet. The SGR and RGR were found to be decreasing with increasing amount of SML diet. The FCR of the control diet did not show significance difference with $10 \%, 70 \%$ and $30 \%$ but showed significance difference between $20 \%, 40 \%$, $50 \%, 80 \%, 90 \%$ and $100 \%$ respectively

The highest value for feed efficiency was observed in $20 \%$ at $30.33 \%$. The FCE of the central diet did not show significant difference with $30 \%, 70 \%$ and $10 \%$ SML meal.

TABLE 2: Growth response and nutrient utilization of feeding $C$. gariepinus with spent millet based diets for 10 weeks

\begin{tabular}{|c|c|c|c|c|c|c|c|c|c|c|c|c|c|c|c|c|c|c|}
\hline \multicolumn{19}{|c|}{ DIETS } \\
\hline Parameter & \multicolumn{2}{|l|}{$0 \%$} & \multicolumn{2}{|l|}{$10 \%$} & \multicolumn{2}{|l|}{$20 \%$} & \multicolumn{2}{|l|}{$30 \%$} & \multicolumn{2}{|l|}{$40 \%$} & \multirow{2}{*}{$\begin{array}{l}50 \% \\
8.33\end{array}$} & \multicolumn{2}{|l|}{$70 \%$} & \multicolumn{2}{|l|}{$80 \%$} & \multirow{2}{*}{$\frac{90 \%}{8.33}$} & \multicolumn{2}{|l|}{$100 \%$} \\
\hline MIW(g) & 8.33 & & 8.33 & & 8.33 & & 8.33 & & 8.33 & & & 8.33 & & 8.33 & & & 8.33 & \\
\hline \multirow{2}{*}{ MFW(g) } & $68.52 \pm$ & & $66.66 \pm$ & & $64.45 \pm$ & & $63.62 \pm$ & & 50.28 & \pm & $49.70 \pm$ & 46.00 & \pm & 43.94 & \pm & $39.33 \pm$ & $37.50 \pm$ & \\
\hline & $2.16^{\mathrm{a}}$ & & $0.60^{\mathrm{ab}}$ & & $2.22^{\mathrm{b}}$ & & $0.01^{\mathrm{b}}$ & & $0.28^{\mathrm{c}}$ & & $0.30^{c}$ & $0.00^{\mathrm{d}}$ & & $0.30^{\mathrm{d}}$ & & $0.33^{\mathrm{e}}$ & $0.00^{\mathrm{e}}$ & \\
\hline \multirow[t]{2}{*}{ MWG (g) } & 60.17 & \pm & 58.33 & \pm & 56.13 & \pm & 55.28 & \pm & $41.94 \pm$ & & $41.37 \pm$ & $37.67 \pm$ & & 35.61 & \pm & $31.00 \pm$ & $29.17 \pm$ & \\
\hline & $2.16^{\mathrm{a}}$ & & $0.61^{\mathrm{ab}}$ & & $2.23^{\mathrm{b}}$ & & $0.01^{\mathrm{b}}$ & & $0.28^{\mathrm{c}}$ & & $0.30^{\mathrm{c}}$ & $0.00^{\mathrm{d}}$ & & $0.30^{\mathrm{d}}$ & & $0.33^{\mathrm{e}}$ & $0.00^{\mathrm{e}}$ & \\
\hline \multirow[t]{2}{*}{ ADW } & 0.86 & \pm & 0.77 & \pm & 0.80 & \pm & 0.79 & \pm & 0.60 & \pm & 0.59 & 0.54 & \pm & 0.51 & \pm & $0.44 \pm$ & 0.42 & \pm \\
\hline & $0.03^{\mathrm{a}}$ & & $0.06^{\mathrm{b}}$ & & $0.03^{\mathrm{ab}}$ & & $0.00^{\mathrm{abc}}$ & & $0.00 \mathrm{c}$ & & $0.01^{\mathrm{c}}$ & $0.00^{\mathrm{cd}}$ & & $0.01^{\mathrm{de}}$ & & $0.00^{\mathrm{ef}}$ & $0.00^{\mathrm{f}}$ & \\
\hline \multirow[t]{2}{*}{ SGR } & 85.90 & \pm & $83.53 \pm$ & & 80.16 & \pm & $78.98 \pm$ & & $59 . .92 \pm$ & & $59.09 \pm 6$ & $50.87 \pm$ & & $60.48 \pm$ & & $47.62 \pm$ & 41.67 & \pm \\
\hline & $3.09^{\mathrm{a}}$ & & $0.67^{\mathrm{a}}$ & & $3.18^{\mathrm{a}}$ & & $0.02^{\mathrm{a}}$ & & $0.40^{\mathrm{b}}$ & & $.67^{\mathrm{b}}$ & $0.43^{\mathrm{c}}$ & & $6.67^{\mathrm{c}}$ & & $3.12^{\mathrm{cd}}$ & $0.00^{\mathrm{d}}$ & \\
\hline \multirow[t]{2}{*}{ RGR } & 722.53 & \pm & 700.28 & \pm & $673.67 \pm$ & & $663.67 \pm$ & & $503.56 \pm$ & & 496.60 & 458.89 & \pm & 427.53 & & 372.19 & $350.18 \pm$ & \\
\hline & $25.98^{\mathrm{a}}$ & & $7.28^{\mathrm{a}}$ & & $26.69^{b}$ & & $0.16^{\mathrm{b}}$ & & $3.32^{\mathrm{c}}$ & & $\pm 3.64^{\mathrm{c}}$ & $6.67^{\mathrm{d}}$ & & $\pm 3.64^{\mathrm{d}}$ & & $\pm 4.00^{\mathrm{e}}$ & $0.00^{\mathrm{e}}$ & \\
\hline \multirow[t]{2}{*}{ FCR } & 3.75 & \pm & 3.70 & \pm & 3.32 & \pm & 3.84 & \pm & 4.29 & \pm & $4.29 \pm 0$. & 3.69 & \pm & 4.24 & \pm & $4.16 \pm$ & 4.91 & \pm \\
\hline & $0.15^{\mathrm{c}}$ & & $0.15^{\mathrm{c}}$ & & $0.13^{\mathrm{d}}$ & & $0.03^{\mathrm{c}}$ & & $0.01^{\mathrm{b}}$ & & $03^{\mathrm{b}}$ & $0.02^{\mathrm{c}}$ & & $0.03^{\mathrm{b}}$ & & $0.04^{\mathrm{b}}$ & $0.03^{\mathrm{a}}$ & \\
\hline \multirow[t]{2}{*}{ FCE } & 26.73 & \pm & 27.14 & \pm & 30.16 & \pm & $26.04 \pm$ & & 23.40 & \pm & $23.33 \pm$ & 27.13 & \pm & 23.59 & \pm & $24.06 \pm$ & 20.35 & \pm \\
\hline & $1.03^{\mathrm{b}}$ & & $1.06^{\mathrm{b}}$ & & $1.12^{\mathrm{a}}$ & & $0.22^{\mathrm{b}}$ & & $1.05^{\mathrm{d}}$ & & $0.15^{\mathrm{d}}$ & $0.00^{\mathrm{d}}$ & & $0.14^{\mathrm{d}}$ & & $0.23^{\mathrm{d}}$ & $0.31^{\mathrm{e}}$ & \\
\hline \multirow[t]{2}{*}{ PER } & 0.67 & \pm & 0.68 & \pm & 0.75 & \pm & 0.65 & \pm & 0.59 & \pm & $0.58 \pm$ & 0.68 & \pm & 0.59 & \pm & $0.60 \pm$ & 0.51 & \pm \\
\hline & $0.03^{\mathrm{b}}$ & & $0.03^{\mathrm{b}}$ & & $0.03^{\mathrm{a}}$ & & $0.01^{\mathrm{b}}$ & & $0.03^{\mathrm{c}}$ & & $0.01^{\mathrm{c}}$ & $0.00^{\mathrm{b}}$ & & $0.00^{\mathrm{c}}$ & & $0.01^{\mathrm{c}}$ & $0.00^{\mathrm{d}}$ & \\
\hline \multirow[t]{2}{*}{ Mortality } & 3.11 & \pm & 8.33 & \pm & $22.22 \pm$ & & 8.33 & \pm & $2.78 \pm$ & & $8.33 \pm$ & 16.67 & \pm & 8.33 & \pm & $16.67 \pm$ & $0.00 \pm$ & \\
\hline & $2.73^{\mathrm{a}}$ & & $0.00^{\mathrm{b}}$ & & $2.78^{\mathrm{a}}$ & & $0.00^{\mathrm{b}}$ & & $2.78^{\mathrm{b}}$ & & $0.00^{\mathrm{b}}$ & $0.00^{\mathrm{ab}}$ & & $0.00^{\mathrm{b}}$ & & $0.00^{\mathrm{a}}$ & $0.00^{\mathrm{b}}$ & \\
\hline \multirow[t]{2}{*}{ Survival rate } & 86.11 & \pm & 91.67 & \pm & 77.78 & \pm & 91.67 & \pm & 97.22 & \pm & $91.67 \pm$ & $83.33 \pm 0$ & & 88.89 & \pm & $83.33 \pm$ & $100 \pm$ & \\
\hline & $2.78^{\mathrm{cd}}$ & & $0.00^{\mathrm{bc}}$ & & $2.78^{\mathrm{e}}$ & & $0.00^{\mathrm{bc}}$ & & $2.78^{\mathrm{ab}}$ & & $0.00^{\mathrm{bc}}$ & $00^{\mathrm{d}}$ & & $2.78^{\mathrm{cd}}$ & & $0.00^{\mathrm{d}}$ & $0.00^{\mathrm{b}}$ & \\
\hline
\end{tabular}

PER (protein efficiency ratio) of the control diet did not show significant difference from fishes fed with $50 \%, 80 \%, 40 \%, 90 \%, 70 \%, 10 \%$ and $20 \%$. Mortality rate was the highest in $20 \%$ as $22.22 \%$ and lowest in $100 \%$ at $0.00 \%$.
Survival rate (SR) was highest in $100 \%$ SML meal at $100 \%$ followed by $40 \%$ SM meal at $97.22 \%$.SR was lowest in $20 \%$ SML meal at $77.77 \%$ 
Table 3: Proximate composition of spent millet from locally

\begin{tabular}{ll}
\multicolumn{2}{c}{ fermented drink (Oburukutu) } \\
\hline Parameter & Millet \\
\hline Moisture content & $5.35 \pm 0.01$ \\
Ash content & $5.26 \pm 0.01$ \\
Fibre content & $3.80 \pm 0.28$ \\
Fat content & $2.53 \pm 0.01$ \\
Crude protein & $14.60 \pm 0.00$ \\
Carbohydrate & $68.63 \pm 0.00$ \\
\hline
\end{tabular}

Water quality parameters: In general low levels of dissolved oxygen, temperature and water $\mathrm{pH}$ tend to retrogressively affect the growth performances of fish (Summerfelt, 2000). In this study the mean water characteristics values of dissolved oxygen, temperature and $\mathrm{pH}$ were within the recommended levels as shown in Table 4.3 for rearing the African catfish. The physicochemical water quality parameter of fish for experiment is presented in table 4. The physicochemical water quality parameter of fish culture environment were observed throughout the period of the experiment. In this study, the water quality parameters such as temperature. $\mathrm{pH}, \mathrm{NH}_{3}, \mathrm{NO}_{3}$ and $\mathrm{NO}_{2}$ are within the optimum range and did not show any adverse effect on the growth of the experimented fish.

\begin{tabular}{lllllll}
\multicolumn{5}{c}{ Table 4: Weekly water quality parameters throughout duration of the experiment } \\
\hline WEEKS & $\begin{array}{l}\text { DISSOLVED } \\
\text { OXYGEN }\end{array}$ & $\mathrm{pH}$ & $\mathrm{T}(\mathrm{C})$ & $\begin{array}{l}\mathrm{NH}_{3} \\
(\mathrm{mg} / \mathrm{L})\end{array}$ & $\begin{array}{l}\mathrm{NO}_{2} \\
(\mathrm{mg} / \mathrm{L})\end{array}$ & $\begin{array}{l}\mathrm{NO}_{3} \\
(\mathrm{mg} / \mathrm{L})\end{array}$ \\
\hline 1 & 5.30 & 7.94 & 20.33 & 0.06 & 0.122 & 4.2 \\
2 & 5.762 & 7.13 & 21.22 & 0.27 & 0.120 & 5.1 \\
3 & 5.00 & 7.70 & 22.43 & 0.13 & 0.425 & 7.3 \\
4 & 5.80 & 7.82 & 22.40 & 0.07 & 0.453 & 7.3 \\
5 & 5.50 & 7.20 & 22.53 & 0.14 & 0.194 & 11.9 \\
6 & 6.12 & 7.30 & 21.10 & 0.31 & 0.344 & 13.4 \\
7 & 6.33 & 7.8 & 22.00 & 0.16 & 0.271 & 13.5 \\
8 & 6.40 & 7.61 & 23.65 & 0.10 & 0.761 & 13.5 \\
9 & 5.40 & 7.34 & 21.40 & 0.15 & 0.328 & 14.5 \\
10 & 5.80 & 87.30 & 22.40 & 0.23 & 0.223 & 8.6 \\
\hline
\end{tabular}

Brewer's waste has been utilized as livestock fed since the inception of beer production (Westendorf and Wohlt 2002). Its wide spread availability makes it a good for alternative carbohydrates protein sources for aqua feeds, especially in the developing regions of tropics. This is basically because of the lack of sufficient plant protein sources like soybean in these parts of the world. Brewery waste (BSW and MBW), a by-product of brewery industry, is high in nutritional value. Previously, BSW and MBW had been considered to be an industrial waste that required special treatment. The results of the present study showed that the inclusion level of BSW and MBW up to $70 \%$ had no negative effect on growth response as represented by final weight, weight gain, SGR and survival compared to the control diets. However, FCR was affected by feeding different inclusion levels of spent sorghum, maize and millet from BKT production. Poor feed efficiency, in experimental feed containing high SSG, SMZ and SML can be explained by the less palatability of the diets when the feed contains a high level of the spent grain from BKT (Eyo and Ezechie, 2004). It has also been reported that different starch and protein sources affected the physical quality of extruded fish diets which can in turn affect its palatability and acceptability ( $\varnothing$ verland et al. 2009; Sørensen et al., 2010). Another basic explanation to the growth differentials among the treatment groups may be the imbalance in the digestible energy of the test diets (Eyo, 2004), since energy of the test diets were observed to decrease with increase in the level of the spent grain from BKT production in the diets.

Carbohydrates are generally cheaper dietary energy sources than protein and lipids. However, fish species show different capacity to digest and metabolize alternative dietary components, in particular the carbohydrate fraction (Dabrowski and Guderley, 2002; Hemre et al., 2002). The digestion and metabolism of feed ingredients is dependent on fish species, source, inclusion level and treatment of the ingredient (Krogdahl et al., 2005). The bioavailability of nutrients and energy in feedstuffs for catfish may be defined mainly in terms of digestibility or, in the case of energy, metabolizability. Digestibility describes the fraction of the nutrient or energy in the ingested feedstuff that is not excreted in the faeces Metabolizability describes the fraction of the digested energy that is not excreted in the urine and through the gills. The Apparent protein digestibility values in various ingredients of plant origin have been reported. Hossain et al. (1997) reported 76.2\%-94.0\% in Rohu, $78.9 \%-85.8 \%$ in common carp (Mukhopadhyay, 2001), 52.5\% - 94.1\% in catla (Jafari and Anwar, 1995) and $88.06 \%-91.10 \%$ in $C$. gariepinus (Jimoh et al., 2014). The low carbohydrate digestibility recorded in this study was similar to that reported by Adeparusi and Jimoh (2002) for Oreochromis niloticus fed lima bean and Jimoh et al. (2014) for $C$. gariepinus. The digestibility of carbohydrate has been known to vary with the complexity of carbohydrate, source treatment and 
level of inclusion in the diet. A plausible explanation for the lower digestibility coefficient recorded for crude fibre and carbohydrate in the C.gariepinus fed for both control and test diets maybe as a result of the physiological requirements of the experimental fish as C. gariepinus are reported to be carnivorous (Jimoh et al., 2014). Fagbenro et al. (2013) had similar report when they fed $C$. gariepinus with sunflower and sesame seed meal. Spent millet meal from BKT production gave more growth than Sorghum and maize meal, this may be as result that millet had more crude protein than sorghum and maize, another reason is that the crude fibre in maize and sorghum is low compared to millet.

Conclusion: Spent sorghum were relatively well digested by the experimental fish ( $C$. gariepinus). This is in line with the view that the African catfish should be classified as an omnivorous fish that has the potential to utilize all dietary components, including carbohydrates, more efficiently than many other fish species, It could therefore be suggested that SPENT sorghum meal from BKT production could be used for partial replacement of corn meal in the diets for $C$. gariepinus, as they have a good digestible protein and carbohydrate.

\section{REFERENCES}

Ajanaku, KD; Dawodu, FA; Siyanbola, T. O. (2010). Histopathological studies of brewery spent grain effect in human's food chain. Int. J. of Chem.Environ. Engineering, 1(2): 113 - 116.

Apantaku, SO; Omotayo, AM; Oyesola. AB. (1998). Poultry Farmers ${ }^{\text {ee }}$ Willingness Participate in NAIC Scheme in Ogun State. Procedure of the Silver AnniversaryConference of Nigerian Society of Animal Production, Gateway Hotel, Abeokuta. 21 ${ }^{\text {st }}-26^{\text {th }}$ March, p. 542.

Baruah, K; Sahu NP; Debnath D. (2003). Dietary phytase: An ideal approach for a cost effective and low polluting aquafeed. NAGA, 27(3): 15 19.

Brown ME. (1975). Experimental Studies on Growth. The physiology of fishes. In: Brown M.E. (ed). Vol. I Academic Press, London 401pp.

Egemba, CK; Etuk, VE. (2007). A Kinetic Study of Burukutu Fermentation. J.of Eng and Applied Sci. 2(7): 1193-1198.

Ejeta, G; Grenier, C. (2005) Chapter 8: Sorghum and its weedy hybrids. In: Crop Ferality and
Volunteerism, Gressel, J., ed . CRC Press, Boca Raton, Florida, USA. 123-135.

Eyo, AA. (2004). Fundamentals of fish nutrition and diet development an overview. Pp. 133. In A.A. Eyo (Editor). National workshop on fish feed development and feeding practices in aquaculture NIFFRI, Newbussa 15th to 19th September

Eyo, JE; Ezechie, CV. 2004. The effects of rubber (Havea brasiliensis) seed meal based diets on diets acceptability and growth performance of Heterobranchus bidorsalis (male) $\mathrm{x}$ Clarias gariepinus (female) hybrid. Journal of sustainable Tropical

Fagbenro, OA; Adeparusi, EO; Jimoh, WA. (2013). Apparent nutrient digestibility of sunflower and sesame seed meal in Clarias gariepinus (Burchell, 1822) Fingerlings.

FAO (Accessed: 27-8-2015) Sorghum bicolor (L.) Moench.

FAO Fisheries and Aquaculture Department, 2013. The State of World Fisheries and Aquaculture 2012.

FAO Fisheries Technical Paper. No. 497. FAO, Rome.

FAO. (2011). the state of world fisheries and aquaculture 2012. Food and Agriculture Organization of the United Nation 00153 Rome, Italy

Fasuyi, AO. (2005). Nutritional evaluation of cassava (Manihot esculenta) leaf protein concentrate (CLPC) as alternative protein sources in rat assay. Pakistan. J. Nutrition, 4: 50-56.

Halver (1976). Formulating Practical diets for fish. Fish Res. Board Canada. 33:1032 1039.

Heyde, GI; Mommsen, TP; Krogdahl, A. (2010). Carbohydrates in fish nutrition.

Hossain, M A. ; Beveridge, M. C. M; Haylor, G. S. (1998). The effects of density, light and shelter on the growth; survival of African catfish (Clarias gariepinus Burchell,

Huntington, TC; Hasan, MR., (2009). Fish as feed inputs for aquaculture- practices, sustainability and implications: a global synthesis. In: Hasan, M.R. and Halwart, M., eds. Fish as feed inputs for 
aquaculture: practices, sustainability and implications. Rome: FAO, pp. 1-61.

Ighwela, KA; Ahmed, BA; Abol-Munafi, AB. (2014). Evaluation of apparent digestibility coefficients of different dietary maltose levels in Nile tilapia (Oreochromis niloticus) fingerlings. Res. J. Pharm., Biol. Chem. Sci. 5(2): $1014-1018$.

Jiang, H. (2010). Resistant-starch formation in highamylose maize starch (Graduate Theses and Dissertations Paper11351)

Jimoh, WA; Fagbenro, OA; Adeparusi, E. O. (2014). Response of African Catfish,Clarias gariepinus (Burchell 1822), Fingerlings Fed Diets Containing Differently Timed Wet-Heat-Treated Sesame (Sesamum indicum) Seedmeal. Agricultural Scienc 5: 1159 - 1171.

Jimoh, WA; Fagbenro, O. A; Adeparusi, E. O. (2014). Response of African Catfish. Journal of Fisheries and Aquatic Sciences, 8: 43 - 50.

Krogdahl, Å; Hemre, GI; Mommsen, TP. (2005). Carbohydrates in fish nutrition: digestion and absorption in postlarval stages. Aquaculture Nutrition, 11(2): $103-122$.

Lovell RT. (1987). Nutrition and Feeding of Fish. AVI book published by Van M. Nostrand, Reinloll, New York, 260pp.

Mukhopadhyay, N. (2001). Effect of fermentation in apparent total and nutrient digestibility of sesame (Sesamum indicum) seed meal in rohu, Labeo roluta (Hamiltan) fingerlings. Obesity, 17, 40-45.
Mussatto, SI; Dragone, G; Roberto, I.C. (2006). Brewer's spent grains: "generation, characteristics and potential applications", Journal of Cereal Science, 43: 1 - 14.

Nyannor, EKD; Adedokun, SA; Hamaker, BR; Ejeta, G; Adeola, O. (2007). Nutritional evaluation of high digestible sorghum for pigs, J. Animal Science, 85: 196-203.

Øverland, M; Sørensen, M; Storebakken, T; Penn, M; Krogdahl, A; and Skrede, A. (2009).Pea protein concentrate substituting fish meal or soybean meal in diets for Atlantic salmon (Salmo salar): effect on growth performance, nutrient digestibility, carcass composition, gut health, and physical feed quality. Aquaculture, 288: 305 311.

Oyelese, OA. (2007). Utilization of Processed Snail meal and Supplementation with conventional fish meal in the diet of Clarias gariepinus. International journal of fish, 2(2):140-146.

Sørensen, M; Morken, T; Kosanovic, M; Øverland, M. (2010). Pea and wheat starch possess different processing characteristics and affect physical quality and viscosity of extruded feed for Atlantic salmon. Aquaculture Nutrition, 17: 1 - 11.

Westendorf, M.L (2002). Brewing byproducts: their use as animal feeds. The Veterinary Clinics of North America Food Animal Practice 18(2):233252. 